\title{
HAK PEREMPUAN HINDU BALI ATAS HARTA WARISAN SUAMI
}

\author{
Oleh: \\ Desyanti Suka Asih K.Tus' \\ E-mail : desyanti@uhnsugriwa.ac.id \\ Dosen IImu Hukum \\ Universitas Hindu Negeri I Gusti Bagus Sugriwa Denpasar
}

\begin{abstract}
Indonesia does not have a unified regulation regarding inheritance law. This legal pluralism occurs with the application of three different regulations related to inheritance law namely is Western Civil Law, Compilation of Islamic Laws and Customary laws which is applicable based on the region such as Bali Customary Laws. The customary law sourced from the norms, religion, principle that develop within the society. Customary inheritance law is strongly influenced by the family system that applies in every region in Indonesia. Customary inheritance law in Bali is influenced by the patrilineal system adopted in Bali. The patrilineal system adheres to the male line. The patrilineal system places men as the successors of the family including those who are obliged and entitled to family inheritance. This situation makes the position of women as subordinate parties in the family, especially in terms of inheritance. The rights of Hindu women in Bali to her husband's inheritance are often disregarded, forgotten, and abolished. Based on national law, a wife who is left dead by her husband will automatically become an heir. This situation does not necessarily apply to Balinese customary law with the patrilineal system. Social change and demands of the feminist theory have not brought a change to the application of Balinese customary inheritance laws in the community. The presence of provisions in the form of the MUDP (an Indonesia Governmental Body for Balinese) decision and the Supreme Court's decision have not been able to bring a change to the position of women (widows because of death) as husband's heir. The lack of knowledge and legal awareness of Hindu women in Bali over their position as heirs is one of the causes of the weak position of Hindu women in Bali as heirs. This paper will discuss the rights of Hindu women in Bali for husband's inheritance. This paper uses a normative juridical research method.
\end{abstract}

Keywords: Rights of Hindu Women in Bali, Husband's Inheritance

\section{Abstrak}

Indonesia tidak memiliki unifikasi aturan tentang hukum waris. Pluralisme hukum ini terjadi dengan penerapan tiga peraturan berbeda terkait dengan hukum waris yaitu Hukum Perdata Barat, Kompilasi Hukum Islam dan Hukum Adat yang berlaku berdasarkan wilayah seperti Hukum Adat Bali. Hukum adat bersumber dari norma, agama, prinsip yang berkembang dalam masyarakat. Hukum waris adat sangat dipengaruhi oleh sistem kekeluargaan yang berlaku di setiap daerah di Indonesia. Hukum waris adat di Bali dipengaruhi oleh sistem patrilineal yang dianut di Bali. Sistem patrilineal menganut garis laki-laki. Sistem patrilineal menempatkan laki-laki sebagai penerus keluarga termasuk mereka yang wajib dan berhak atas warisan keluarga. Situasi ini menjadikan posisi perempuan sebagai pihak subordinat dalam keluarga terutama dalam hal warisan. Hak perempuan Hindu di Bali atas harta warisan suaminya seringkali diabaikan, dilupakan, dan dihapuskan. Berdasarkan hukum nasional, istri yang ditinggal mati oleh suaminya dengan sendirinya menjadi ahli waris. Keadaan ini tidak serta merta berlaku untuk hukum adat Bali dengan sistem patrilineal. Perubahan sosial dan tuntutan teori feminis belum membawa perubahan pada penerapan hukum waris adat Bali di masyarakat. Adanya ketentuan berupa putusan MUDP (Badan Pemerintah Indonesia untuk Orang Bali) dan putusan Mahkamah Agung belum mampu mengubah posisi 
perempuan (janda karena meninggal dunia) sebagai ahli waris suami. Minimnya pengetahuan dan kesadaran hukum perempuan Hindu di Bali atas posisinya sebagai ahli waris menjadi salah satu penyebab lemahnya posisi perempuan Hindu di Bali sebagai ahli waris. Makalah ini akan membahas tentang hak-hak perempuan Hindu di Bali atas warisan suami. Makalah ini menggunakan metode penelitian yuridis normatif.

Kata Kunci: Hak Perempuan Hindu Bali, Harta Warisan Suami

\section{PENDAHULUAN}

Masyarakat Indonesia adalah masyarakat yang ber-Bhineka Tunggal lka yang berbeda-beda suku, agama, ras dan antar golongan (SARA), yang kemudian bersatu dalam satu kesatuan Negara Pancasila sejak tanggal 17 Agustus 1945 (Olivia dan Lubis, 2007:131). Pada masa penjajahan, Pemerintah Hindia Belanda mengeluarkan Staatblad 1925 Nomor 415, Pasal 131 Indische Staatregeling (IS) Juncto Pasal 163 ayat (1) IS, yang membagi penduduk Indonesia dalam 3 (tiga) golongan, yaitu: (1) Golongan Eropa, (2) Golongan Pribumi dan (3) Golongan Timur Asing (Benni, 2015:2). Pada masing-masing golongan tersebut berlaku pula Hukum Perdata tersendiri, yaitu bagi Golongan Eropa berlaku Hukum Perdata Barat (Burgerlijk Wetboek), bagi Golongan Pribumi berlaku hukum adat, sedangkan bagi Golongan Timur Asing berlaku Hukum Perdata Barat (Benni, 2015:2). Pembagian golongan penduduk di Indonesia oleh Pemerintah Hindia Belanda berpengaruh pada hukum waris yang berlaku. Hukum waris merupakan salah satu bagian dari Hukum Perdata di Indonesia. Di Indonesia belum terdapat kodifikasi mengenai hukum waris. Hal ini berarti terhadap penerapan hukum waris di Indonesia masih berbeda-beda. Pemberlakuan hukum waris di Indonesia dibagi menjadi 3 (tiga) yaitu: (1) Hukum waris Adat, (2) Hukum waris Islam dan (3) Hukum waris Barat. Pemberlakuan ketiga aturan hukum waris tersebut menunjukkan bahwa di Indonesia terdapat pluralisme dalam hukum waris. Pluralime tersebut masih berlaku hingga saat ini.

Hukum waris Barat berlaku bagi mereka yang tunduk pada Hukum Perdata Barat. Terhadap mereka berlaku ketentuan-ketentaun dalam Kitab Undang-Undang Hukum Perdata (KUH Perdata). Dalam KUH Perdata, hukum waris diatur Bersama-sama dengan hukum benda. Ada 2 (dua) alasan pembentuk undang-undang menempatkan hukum waris dalam Buku ke-Il: (1) hukum waris dianggap sebagai suatu hak kebendaan (Pasal 528 KUH Perdata), dan (2) hukum waris merupakan salah satu cara yang ditentukan secara limitatif oleh undang-undang untuk memperoleh hak milik (Pasal $584 \mathrm{KUH}$ Perdata) (Simanjuntak ,2017:209-210). Hukum waris Islam berlaku bagi mereka yang beragama Islam yang pengaturannya terdapat dalam Al-Qur'an dan sebagai pelengkapnya dipakai Sunnah Nabi beserta hasil-hasil ijtihad para ahli hukum Islam. Hukum waris Islam diatur pula dalam Instruksi Presiden No.1 Tahun 1991 tentang Kompilasi Hukum Islam (Pasal 171-214 KHI) (Simanjuntak ,2017:209-210). Hukum waris Adat adalah hukum waris yang berlaku orang Indonesia asli. Hukum waris adalah bagian dari hukum adat. Pemberlakuan hukum waris Adat di masing-masing daerah di Indonesia berbeda-beda. Misalnya hukum waris adat Bali, hukum waris adat Minangkabau, hukum waris adat Jawa, hukum waris adat Kalimantan. 
Hukum waris sebagai bagian dari hukum adat di akui keberadaannya dan tetap mengkar kuat dalam masyarakat Indonesia. Pengakuan tersebut tercermin dari ketentuan Pasal 18B ayat (2) UUDNRI yang berbunyi "Negara mengakui dan menghormati kesatuan-kesatuan masyarakat hukum adat serta hak-hak tradisionalnya sepanjang masih hidup dan sesuai dengan perkembangan masyarakat dan prinsip-prinsip Negara Kesatuan Rapublik Indonesia, yang diatur dalam undang-undang". Keberadaan hukum adat diakui pula sebagai bagian dari HAM. Ketentuan Pasal 67 UU No.39 Tahun 1999 Tentang Hak Asasi Manusia menyebutkan "Setiap orang yang ada di wilayah Negara Republik Indonesia wajib patuh pada peraturan perundang-undangan, hukum tak tertulis, dan hukum internasional mengenai hak asasi manusia yang telah diterima oleh Negara Republik Indonesia." Hukum tak tertulis yang dimaksud dalam UU HAM adalah hukum adat. Wirjono

Prodjodikoro menyatakan waris dalam hukum waris adalah perihal soal apakah dan bagaimanakah hak-hak dan kewajiban-kewajiban tentang kekayaan seseorang pada waktu ia meninggal dunia akan beralih kepada orang lain yang masih hidup (Soerojo Wignjyodipoero, 1982:161). Pewarisan merupakan suatu proses beralihnya harta kekayaan seseorang kepada ahli warisnya yang terjadi hanya karena kematian. Oleh karena itu pewarisan baru akan terjadi jika terpenuhi 3 persyaratan, yaitu:

1.Ada seseorang yang meninggal dunia;

2.Ada seseorang yang masih hidup sebagai ahli waris yang akan menerima sejumlah harta peninggalan pada saat pewaris meninggal dunia. Ahli waris atau para ahli waris harus ada pada saat pewaris meninggal dunia. Ketentuan ini tidak berarti mengurangi makna Pasal 2 B.W yaitu: "anak yang ada dalam kandungan seorang perempuan dianggap sebagai telah dilahirkan, bilamana kepentingan si anak menghendakinya."Apabila ia meninggal saat dilahirkan, ia dianggap tidak pernah ada. Dengan demikian berarti bayi dalam kandungan juga sudah diatur haknya oleh hukum sebagai ahli waris dan telah dianggap cakap untuk mewaris

3.Ada sejumlah harta kekayaan yang ditinggalkan pewaris (Suparman, E., \& Gunarsa, A., 2005:25-32).

Mengenai ahli waris menurut undang-undang, dalam Pasal 832 KUH Perdata dinyatakan:

Menurut undang-undang, yang berhak menjadi ahli waris ialah keluarga sedarah, baik yang sah menurut undang-undang maupun yang di luar perkawinan, dan si suami atau si istri yang hidup terlama, menurut peraturan-peraturan berikut ini. Bila keluarga sedarah dan si suami atau si istri yang hidup terlama tidak ada, maka semua harta peninggalan menjadi milik negara, yang wajib melunasi utang-utang orang yang meninggal tersebut, sejauh harga harta peninggalan mencukupi untuk itu.

Hukum waris merupakan bagian dari bidang hukum adat kekeluargaan yang sangat erat kaitannya dengan system kekerabatan yang dianut oleh suatu masyarakat tertentu. Di Indonesia pada prinsipnya dikenal 3 (tiga) system kekerabatan atau tiga cara melihat garis keturunan:

1.Patrilinieal. Garis keturunan yang semata-mata hanya dilihat menurut garis laki-laki atau garis ayah. System ini dianut di daerah Batak, Lampung, Bali, Gayo, Ambon, Buru, Nias.

2.Matrilineal. Pertalian keturunan yang semata-mata dilihat menurut garis perempuan saja atau garis ibu. System ini dianut di Minangkabau, Kerinci. 
3.Parental. Garis keturunan dilihat baik menurut garis laki-laki (ayah) maupun menurut garis perempuan (ibu) atau menurut garis dua sisi (ayah - ibu), dimana kedudukan lai-laki dan peremuan tidak dibedakan. System ini dianut di daerah Aceh, Bugis, Riau, Kalimantan dan Jawa (Bushar, 1988:24).

Masyarakat Bali, menganut system kekeluargaan patrilineal dimana garis keturunan ditarik dari garis laki-laki yang membawa konsekuensi penerusan harta warisan berada pada anak (keturunan) lakilaki, sedangkan anak perempuan tidak diperhitungkan dalam pewarisan (Sukerti, 2011:87). Berkaitan dengan hukum waris adat yang menempatkan anak laki-laki sebagai penerus harta warisan, maka yang menjadi pokok kajian dalam tulisan ini adalah hak waris dari perempuan. Perempuan dalam kedudukannya sebagai janda. Janda karena ditinggal mati oleh suami. Yang mana kedudukan janda tersebut seharusnya adalah sebagai ahli waris dari suami. Sementara pada kenyataannya masih sering terjadi perlakuan yang tidak adil. Posisi istri (janda) yang ditinggal meninggal oleh suami dalam hukum waris adat, seringkali tidak diakui sebagai pewaris dari harta peninggalan suami. System patrilineal yang berlaku sering menyebabkan kedudukan janda diabaikan, dilupakan, bahkan diabaikan haknya. Terlebih ketika selama perkawinan tidak memiliki keturunan. Kedudukan janda semakin lemah dan semakain terabaikan. Anggapan bahwa anak perempuan dan janda bukan hali waris menjadi momok bagi pemenuhan hak janda sebagai ahli waris dari harta peninggalan suami. timbal balik dalam masalah pidana.

\section{METODE}

Tulisan ini kaji menggunakan metode yuridis normative. Pendekatan yuridis normative dilakukan dengan mengkaji norma-norma yang berkaitan dengan Hak Perempuan Hindu Bali Atas Harta Warisan Suami. Jenis data yang dipergunakan adalah jenis data sekunder dengan mempergunakan sumber data primer yang dipergunakan adalah sumber data sekunder. Tulisan ini kemudian disajikan secara deskriftif.

\section{PEMBAHASAN}

\section{Hukum Waris Adat Bali}

Hukum waris adat Bali dipengaruhi oleh system kekerabatan patrilineal. System patrilineal adalah system kekerabatan yang memperthitungkan keturunan melalui garis laki-laki yang membawa konsekuensi penerusan harta warisan. Artinya harta warisan diwariskan kepada keturunan laki-laki. Adakalanya anak perempuan dapat sebagai ahli waris. Perempuan dalam perkawinan nyentana disebut Sentana Rajeg yaitu perempuan yang berubah status menjadi berstatus hukum lakilaki. Laki-laki dalam perkawinan ini juga berubah status menjadi berstatus hukum perempuan. Perubahan status ini berlaku dalam hukum adat (Sukerti, 2011:87). System perkawinan yang umum berlaku di Bali adalah perkawinana keluar. Dimana seorang anak perempuan kawin dan mengikuti keanggotaan keluarga suami. Anakanak yang lahir dari perkawinan adalah mengikuti garis keturunan ayah. Bentuk perkawinan nyentana berlaku sebaliknya. Dimana laki-laki yang mengikuti keanggotaan perempuan. Anak-anak yang lahir dari perkawinan tersebut akan mengikuti garis keturunan ibu. System perkawinan nyentana merupakan salah satu upaya mempertahankan pemberlakuan system patrilineal di Bali. 
Segala upaya yang dilakukan dengan tujuan mempertahankan system kekerabatan patrilineal merupakan upaya mempertahankan system kewarisan di Bali yang adalah hukum waris adat, kecuali ditegaskan lain oleh pewaris. Soepomo (2003:83) memandang bahwa hukum waris adat menunjukkan corak yang memang typerend bagi aliran pikiran tradisional Indonesia. Hukum adat waris bersendi atas prinsip-prinsip yang timbul dari aliran-aliran pikiran komunal dan konkret dari bangsa Indonesia. Gede Penetje (2004:101) berpendapat bahwa hukum waris adat adalah bagian yang paling sulit dari hukum adat Bali. Hal tersebut disebabkan karena perbedaan-perbedaan di beberapa daerah dalam wilayah hukum Bali (Desa (tempat), Kala (waktu), Patra (keadaan)), baik mengenai (banyaknya) barang-barang yang boleh diwariskan atau mengenai banyaknya bagian masing-masing ahli waris, maupun mengenai putusan-putusan Pengadilan Adat.

Menurut hukum adat harta peninggalan tidak merupakan satu kebulatan homogen yang diwariskan dengan cara yang sama, yaitu:

a. ada harta bawaan yang melekat pada ikatan kerabat, ada harta yang dipupuk dalam ikatan keluarga, ada benda yang termasuk tanda kehormatan,

b. ada benda-benda yang masih terpatri dalam ikatan persekutuan hukum, dalam kesatuan tata susunan rakyat dengan hak ulayat yang masih berpengaruh pada pewarisan harta perseorangan yang ditinggalkan pemiliknya,

c. harta warisan itu dapat dilekati hutang, dapat pula menyandang piutang,

d. bila pewaris tidak mempunyai anak, maka barang asalnya kembali kepada kerabatnya, sedangkan harta pencahariannya jatuh ketangan oleh teman hidupnya yang tinggal (Hadikusuma, 1977:127).

Sistem kekerabatan patrilineal memiliki pandangan transcendental bahwa garis kehidupan keturunan ditarik dari garis yang berstatus hukum purusha. Status purusha pada umumnya adalah laki-laki, kecuali dalam hal anak perempuan berstatus purusha. Bagi masyarakat adat Bali yang berhak mewaris hanya pihak yang berstatus hukum purusha sebagai penerus keturunan dengan kewajiban melakukan pemujaan pada pura leluhur (kawitan). Masyarakat hukum patrilineal adalah masyarakat hukum, di mana para anggotanya menarik garis keturunan ke atas melalui garis bapak, bapak dari bapak terus ke atas, sehingga dijumpai seorang laki-laki sebagai moyangnya (Sugangga,1988:14).

Sistem kekerabatan pada masyarakat patrilineal ini juga mempengaruhi kedudukan janda dan anak perempuan. Kedudukan janda menurut adat bertitik tolak pada asas bahwa wanita sebagai orang asing sehingga tidak berhak mewaris, namun selaku isteri turut memiliki harta yang diperoleh selamanya karena ikatan perkawinan (harta bersama). Oleh sebab itulah, janda pada masyarakat patrilineal ada suatu ketentuan, yaitu apabila janda diintegrasikan ke dalam kerabat suaminya, ia dapat menetap di sana dan mendapat nafkahnya. Akan tetapi, apabila janda tersebut memisahkan diri dari kerabat suaminya, janda tidak akan pernah membawa benda milik suaminya, seakan-akan mewarisinya (Sudiat, 1981:166).

Anak perempuan juga bukan menjadi ahli waris dari harta orang tuanya, apalagi jika anak perempuan tersebut sudah kawin, kecuali anak perempuan tersebut berkedudukan sebagai purusha (disebut sentana 
rajeg). Anak perempuan yang menjadi sentana rajeg memiliki kedudukan seperti anak laki-laki. Masyarakat adat Bali juga belum menerima anak perempuan yang tidak kawin sebagai ahli waris. Anak perempuan yang tidak kawin hanya berhak untuk menikmati harta orang tuanya saja, namun tidak berhak menjadi ahli waris. Perempuan di Bali pada umumnya bukanlah berkedudukan sebagai ahli waris, baik atas harta suaminya, maupun terhadap harta orang tuanya. Kondisi ini disebabkan karena laki-laki dipandang sebagai pemikul kewajiban baik terhadap orang tua, agama, maupun terhadap kewajiban adat di dalam lingkungan sosial masyarakat. Kewajiban tersebut dipandang hanya dapat dilakukan oleh laki-laki sebagai penerus keturunan dalam keluarga. Kondisi ini menyebabkan pandangan umum yang mengatakan bahwa memiliki anak laki-laki di Bali merupakan suatu kewajiban, dan apabila satu keluarga hanya memiliki anak perempuan saja, maka hal ini akan menjadi masalah.

Perempuan di Bali hanya dapat menikmati harta peninggalan dari suami maupun orang tua, namun tidak dapat memilikinya. Dalam struktur sosial kemasyarakatan di Bali kedudukan laki-laki memang lebih dominan daripada perempuan. Sistem hukum dengan dominasi laki-laki ini menempatkan perempuan pada posisi subordinat (Fadjar, 2013:81).

\section{Ketentuan Hukum Internasional}

Patricia Smith (2010:294) dalam tulisannya yang berjudul "Feminist Jurisprudence" menyebutkan:

Patriarchy is the systematic subordination of women to men, and that is the experience that all women share. The point of view of all women is the point of view of those who are subordinated on the basis of their sex regardless of what else may be different about them. Even if some individual personal relationships deviate from this norm, systematic social organization still conforms to it everywhere.

Dalam Universal Declaration of Human Rights disebutkan: "Whereas the peoples of the United Nations have in the Charter reaffirmed their faith in fundamental human rights, in the dignity and worth of the human person and in the equal rights of men and women and have determined to promote social progress and better standards of life in larger freedom." (Sedangkan bangsa-bangsa Perserikatan Bangsa-Bangsa dalam Piagam menegaskan kembali keyakinan mereka pada hak asasi manusia yang fundamental, dalam martabat dan nilai pribadi manusia dan dalam persamaan hak laki-laki dan perempuan dan telah bertekad untuk mempromosikan kemajuan sosial dan standar kehidupan yang lebih baik di kebebasan yang lebih besar).

Kesetaraan dan keadilan antara wanita dan laki-laki (equality dan equity) yakni persamaan hak dan kesempatan serta perlakuan yang sama di segala bidang dan segala kegiatan merupakan ide dasar dari lahirnya Konvensi tentang Penghapusan Segala Bentuk Diskriminasi terhadap Wanita yang disingkat "Konvensi Wanita" atau yang dikenal dengan sebutan lain sebagai Convention on the Elimination of All Forms of Discrimination Against Women (CEDAW). Konvensi tersebut menjadi pernyataan komitmen negaranegara di dunia menekankan kesetaraan dan keadilan antara wanita dan laki-laki (equality dan equity).

CEDAW diadopsi dalam Konvensi perempuan yang memiliki prinsip-prinsip sebagai berikut (Soeroso, 2010:48):

1. Prinsip persamaan substantive, yaitu persamaan hak, kesempatan akses dan penikmatan manfaat. 
2. Prinsip nondiskriminasi.

3. Prinsip kewajiban negara.

Teori perubahan sosial adalah teori yang menganalisis kedudukan perempuan dalam hukum waris adat Bali. Masyarakat bersifat dinamis dan peka akan perubahan. Setiap elemen masyarakat memberikan sumbangan disintegrasi dan perubahan setiap masyarakat berdasarkan pada paksaan yang dilakukan oleh suatu kelompok masyarakat kepada kelompok masyarakat lain (Astiwi, 2007:4). Satjipto Rahardjo perubahan sosial merupakan ciri yang melekat dalam masyarakat. Hal ini disebabkan karena masyarakat itu mengalami suatu perkembangan (Alkostar, A., \& Amin, M. S., 86:35). Soerjono Soekanto (1993:17) mengemukakan bahwa dalam setiap proses perubahan senantiasa akan dijumpai faktor-faktor penyebab terjadinya perubahan, baik yang berasal dari luar masyarakat itu sendiri maupun yang berasal dari luar masyarakat tersebut.

Patirim Sorokin mengemukakan bahwa perkembangan hukum dan gejala-gejala sosial lainnya disesuaikan dengan tahapan-tahapan tertentu yang dilalui oleh setiap masyarakat. Masyarakat berkembang sesuai dengan nilai-nilai tertentu yang sedang menonjol di dalam masyarakat yang bersangkutan. Nilai-nilai tersebut adalah ideational (yaitu kebenaran absolut sebagaimana diwahyukan oleh Tuhan yang Maha Kuasa), sensate (yaitu nilai-nilai yang didasarkan pada pengalaman) dan idealistic (yang merupakan kategori campuran). Hukum dan gejala sosial budaya lainnya terbentuk sesuai dengan bentuk nilai-nilai yang sedang berlaku di dalam masyarakat (Soerjono Soekanto, 2009:107). Hukum merupakan salah satu alat pengendalian sosial, yang lazimnya disebut dengan law enforcement (Soerjono Soekanto, 2009:180).
Apabila hukum itu berlaku efektif maka akan menimbulkan perubahan dan perubahan itu dapat dikategorikan sebagai perubahan sosial (Taneko, 1993:69). Hukum dan masyarakat saling mempengaruhi dalam proses perubahan. Perubahan hukum tidak lepas dari perubahan pola pikir masyarakat sebaliknya, hukum juga dapat digunakan untuk mengubah perilaku masyarakat.

Upaya dalam memberikan keadilan bagi perempuan untuk memperoleh warisan dan berkedudukan sebagai ahli waris tidak lepas dari perubahan sosial yang telah terjadi di dalam masyarakat. Adapun perubahan sosial tersebut adalah sebagai berikut:

a. Perempuan saat ini tidak hanya berkedudukan sebagai ibu rumah tangga saja di dalam keluarga, namun juga turut bekerja membantu perekonomian keluarga, bahkan tidak jarang yang justru menjadi tulang punggung keluarga. Dalam kondisi demikian, maka tidak adil apabila ketika suami meninggal dunia, seorang perempuan hanya berhak untuk menikmati harta kekayaan yang dimiliki dalam perkawinan tersebut dan hak tersebut juga dapat hilang ketika janda kawin lagi. Seorang janda yang kawin lagi harus meninggalkan harta-harta yang dihasilkan, termasuk selama perkawinan dan mengembalikannya kepada keluarga almarhum suami.

b. Anak perempuan yang sudah kawin sering kali melakukan kewajiban terhadap keluarga asalnya, yakni dalam hal pemujaan terhadap leluhur dan dalam merawat orang tua. Pada kehidupan masyarakat Bali saat ini, sudah banyak ditemukan orang tua yang justru tinggal bersama anak perempuannya yang sudah kawin. Perubahan sosial ini perlu direspon dengan persamaan hak bagi anak perempuan untuk menjadi ahli waris 
terhadap orang tuanya, meskipun anak perempuan tersebut tidak berstatus sebagai purusha di keluarga asalnya. I Gede Putra Manu Harum dan A.A. Gede Agung Dharma Kusuma mengatakan "Kaum perempuan Bali memang seharusnya dapat perhatian yang sama dengan kaum laki-laki, karena semasa hidup orang tua kaum perempuan juga melakukan kewajibannya seperti merawat orang tua semasa hidupnya, sehingga layak diperhitungkan sebagai ahli waris."

\section{Ketentuan di Bali}

Beberapa ketentuan yuridis yang berkaitan dengan hak waris perempuan Bali telah lahir sebagai bentuk pengakuan terhadap kaum feminist khususnya perempuan. Menurut Barlett, feminist yang berhubungan dengan hukum paling tidak memfokuskan pada tiga faktor. Adapun faktor-faktor itu meliputi:

a. Bertanya pada perempuan. Yaitu apa yang perlu ditanyakan seringkali adalah suara bisu (silence), suara yang diasingkan. Menurut Barlett hal ini menyebabkan dengan melihat permukaan hukum untuk mengidentifikasikan implikasi atruran gender dan asumsi yang tidak mengekalkan subordinasi wanita.

b. Metode ini mengistimewakan suatu pemahaman praktis feminist yang dapat mencakup semua logika deduktif, tetapi mempertimbangkan logika pengalaman-pengalaman konkrit dan unik.

c. Munculnya kesadaran. Tujuannya adalah untuk individual dan pemberdayaan kolektif, bukan untuk dendam pribadi (Salman dan Susanto, 2009:135).

Menurut teori ini, mayoritas tatanan hukum dibangun atas pandangan dunia yang bias dimana hukum dikonstruksikan dalam logika laki-laki. Perempuan dikonstruksikan berada pada posisi yang lebih rendah daripada laki-laki. Pandangan inilah yang mendapatkan perlawanan dari penganut teori Legal Feminisme. Perlawanan ditunjukkan dengan Gramsci yakni peningkatan kesadaran ideologi. Penggunaan jalur ini penting, oleh karena perempuan sudah terpenjara dalam ideologi keutamaan laki-laki. Mereka berada dalam kesadaran palsu (false consciousness) tentang realitas dunia (yang mengunggulkan laki-laki), seolah realitas itu memang normal adanya, alamiah dan tidak dapat dirubah. Selama kaum hawa masih terkurung dalam kesadaran palsu dan belum memiliki kesadaran terhadap dunia tempat mereka berada, maka peminggiran dan diskriminasi gender akan terus terpelihara (Tanya, Simanjuntak, dan Hage, 2010:182183).

Teori ini berasumsi bahwa pada dasarnya tidak ada perbedaan antara laki-laki dan perempuan. Karena itu perempuan harus mempunyai hak yang sama dengan laki-laki. Meskipun demikian, kelompok feminis liberal menolak persamaan secara menyeluruh antara laki-laki dan perempuan. Dalam beberapa hal masih tetap ada pembedaan (distinction) antara laki-laki dan perempuan. Bagaimanapun juga, fungsi organ reproduksi bagi perempuan membawa konsekuensi logis dalam kehidupan bermasyarakat (Megawangi, 1999:228).

$\begin{array}{ccc}\text { Pasamuhan Agung III } & \text { Majelis } \\ \text { Utama Desa Pakraman Bali }\end{array}$ memutuskan mengenai kedudukan suami istri dan anak terhadap harta pusaka dan harta gunakaya sebagai berikut.

a. Suami dan istrinya serta saudara laki-laki suami dan istrinya, mempunyai kedudukan yang sama dalam usaha untuk menjamin 
bahwa harta pusaka dapat diteruskan kepada anak dan cucunya untuk memelihara atau melestarikan warisan immateriil.

b. Selama dalam perkawinan, suami dan istrinya mempunyai kedudukan yang sama terhadap harta gunakayanya (harta yang diperoleh selama dalam status perkawinan).

c. Anak kandung (laki-laki atau perempuan) serta anak angkat (lakilaki atau perempuan) yang belum kawin, pada dasarnya mempunyai kedudukan yang sama terhadap harta gunakaya orangtuanya.

d. Anak kandung (laki-laki atau perempuan) serta anak angkat (lakilaki atau perempuan) berhak atas harta gunakaya orangtuanya, sesudah dikurangi sepertiga sebagai duwe tengah (harta bersama), yang dikuasai (bukan dimiliki) oleh anak yang ngumubang (melanjutkan swadharma atau tanggung jawab) orangtuanya.

e. Anak yang berstatus kapurusa berhak atas satu bagian dari harta warisan, sedangkan yang berstatus pradana/ninggal kadaton terbatas berhak atas sebagian atau setengah dari harta warisan yang diterima oleh seorang anak yang berstatus kapurusa.

f. Dalam hal pembagian warisan, anak yang masih dalam kandungan mempunyai hak yang sama dengan anak yang sudah lahir, sepanjang dia dilahirkan hidup.

g. Anak yang ninggal kadaton penuh tidak berhak atas harta warisan, tetapi dapat diberikan bekal (jiwa dana) oleh orangtuanya dari harta gunakaya tanpa merugikan ahli waris (Bali Sruti. Keputusan Majelis \begin{tabular}{lll} 
Utama Desa & Pakraman Bali \\
\hline (MUDP) & Bali,,
\end{tabular} http://www.balisruti.or.id/keputusanmajelis-utama-desa-pakraman-balimudp-bali.html. Accessed April $7^{\text {th }}$ 2018).
Perkembangannya, kedudukan anak perempuan sebagai ahli waris sudah mulai diperhatikan oleh kalangan tokoh adat di Bali. Keputusan Pesamuhan Agung Majelis Utama Desa Pakraman Bali Nomor 01/KEP/PSM-3/MDP Bali/X/2010, tanggal 15 Oktober 2010 memberikan hak waris bagi anak perempuan yang ninggal kadaton terbatas. Mereka yang ninggal kedaton terbatas dimungkinkan mendapatkan harta warisan didasarkan atas asas ategen asumun (dua berbanding satu), dengan saudaranya yang berstatus purusa. Ninggal kedaton terbatas yaitu ninggal kedaton tetapi dalam batas tertentu masih memungkinkan melaksanakan swadharma (kewajiban) sebagai umat Hindu (Windia, Wiasti, Arjani, 2012:80). Berdasarkan Keputusan tersebut, golongan ninggal kadaton terbatas adalah sebagai berikut.

1. Perempuan yang melangsungkan perkawinan biasa.

2. Laki-laki yang melangsungkan perkawinan nyentana/nyeburin.

3. Telah diangkat anak (kaperas sentana) oleh keluarga lain sesuai dengan agama Hindu dan hukum adat Bali.

4. Menyerahkan diri (makidihang raga) kepada keluarga lain atas kemauan sendiri.

Keputusan Pesamuhan Agung Majelis Utama Desa Pakraman Bali Nomor 01/KEP/PSM-3/MDP Bali/X/2010 telah membawa perubahan besar dalam sistem kewarisan adat Bali dari yang sebelumnya sama sekali tidak memperhatikan kedudukan anak perempuan sebagai ahli waris, menjadi diperhitungkan untuk mendapatkan warisan atas harta benda yang diperoleh oleh orang tuanya. Meskipun aturan mengenai hak waris perempuan sudah ada sebelumnya, namun ketentuan ini 
belum diterima sepenuhnya oleh masyarakat Bali. Pro dan kontra atas keputusan Majelis Utama Desa Pakraman masih terus terjadi. Beberapa putusan pengadilan di Bali telah memutuskan bahwa perempuan menjadi ahli waris. Sayangnya masih banyak masyarakat Bali yang mengabaikan ketentuan-ketentuan tersebut dengan menggunakan dalih hukum adat.

Kedudukan perempuan sebagai ahli waris dalam hukum waris Bali baik terhadap peninggalan suaminya, maupun terhadap peninggalan orang tuanya sebenarnya telah didukung oleh Keputusan Pesamuhan Agung Majelis Utama Desa Pakraman Bali Nomor 01/KEP/PSM-3/MDP Bali/X/2010, tanggal 15 Oktober 2010 yang memberikan pembagian harta warisan kepada anak perempuan yang telah kawin keluar. Terkait dengan keputusan tersebut, pakar hukum adat Bali Wayan P. Windia mengatakan sebagai berikut:

Sesudah 2010 wanita Bali berhak atas warisan berdasarkan Keputusan Pesamuan Agung III MUDP Bali No. 01/Kep/PSM-3MDP Bali/X/2010, 15 Oktober 2010. Di SK ini, wanita Bali menerima setengah dari hak waris purusa setelah dipotong 1/3 untuk harta pusaka dan kepentingan pelestarian. Hanya jika kaum wanita Bali yang pindah ke agama lain, mereka tak berhak atas hak waris. Jika orangtuanya ikhlas, tetap terbuka dengan memberikan jiwa dana atau bekal sukarela (Hukum Online, "Hak Waris Perempuan Menurut Hukum Adat Bali",

http://www.hukumonline.com/klinik/det ail//t4f6ac3987ac0e/hak-warisperempuan-menurut-hukum-adat-bali-, Accessed on April $7^{\text {th }}$ 2018).

Pergeseran terhadap karakteristik pewarisan bagi perempuan juga dapat dilihat pada putusan pengadilan. Dalam Putusan
Pengadilan Tinggi Bali tanggal 7 November $1967 \quad$ No. 228/PDT/1966/PDT dinyatakan "janda adalah ahli waris dari suaminya yang telah meninggal dunia, apabila tidak meninggalkan anak."

Ketentuan dalam hukum waris adat Bali ditegaskan dalam putusan pengadilan yang mengadili kasus sengketa waris di Bali. Putusan hakim yang juga menentukan ahli waris adalah Putusan Mahkamah Agung tanggal 3 Desember 1958, Nomor 200 K/SIP/1958. Dalam putusan tersebut dinyatakan bahwa menurut hukum Adat Bali yang berhak mewaris hanyalah keturunan pria dan pihak keluarga pria dan anak angkat lelaki. Menurut hukum Adat Bali yang berhak mewaris hanyalah keturunan pria dan pihak keluarga pria dan anak angkat lelaki; maka Men Sardji sebagai saudara perempuan bukanlah akhli waris. Putusan Mahkamah Agung Nomor 4766 K/Pdt/1998 tertanggal 16 November 1999 yang menyatakan bahwa anak perempuan di Bali berhak atas harta peninggalan dari pewaris. Dalam Putusan Mahkamah Agung tanggal $23 \quad$ Oktober 1961, No.179/K/SIP/1961 dinyatakan anak laki-laki maupun anak perempuan di tanah Karo berhak atas warisan orang tua dalam arti bagian anak laki--laki sama dengan anak perempuan. Dalam pertimbangan hukumnya disebutkan:

berdasarkan perikemanusiaan dan keadilan umum, dan atas hakekat persamaan hak antara laki-laki dengan perempuan, memandang sebagai hukum yang hidup di seluruh Indonesia bahwa anak perempuan di sampingnya anak laki-laki harus dianggap sebagai ahli waris, sehingga memiliki hak mewaris dari orang tuanya.

Ketentuan-ketentuan yuridis sebagaimana yang diuraikan di atas memang telah ada, namun ketentuan tersebut belum diatur lebih jauh dalam 
awig-awig (Pasal 1 angka 11 Peraturan Daerah Provinsi Bali Nomor 3 Tahun 2001 tentang Desa Pakraman Awig-awig adalah aturan yang dibuat oleh karma desa pakraman dan atau krama banjar pakraman yang dipakai sebagai pedoman dalam pelaksanaan Tri Hita Karana sesuai dengan desa mawacara dan dharma agama di desa pakramanAianjar pakraman masingmasing). Ketentuan-ketentuan yuridis tersebut sejalan dengan teori feminis, namun pada kenyataannya keberadaan ketentuan-ketentuan tersebut masih sering diabaikan yang mengakibatkan kedudukan perempuan (janda) sebagai ahli waris lemah bahkan diabaikan. Perubahan social yang terjadi tidak cukup merubah paradigma dalam masyarakat Hindu di Bali dengan system patrilineal yang beranggapan bahwa perempuan berhak sebagai pewaris. Perempuan tidak hanya berhak memanfaatkan harta warisan keluarga atau almarhum suami. Perempuan berhak memilikinya. Harta warisan peninggalan suami adalah menjadi hak istri yang ditinggalkan (jika tidak ada anak yang dilahirkan dari perkawinan tersebut).

\section{PENUTUP}

Pluralism hukum waris yang berlaku di Indonesai mengakibatkan pemberlakuan aturan yang berbedabeda atas hukum waris. Hukum waris Barat berlaku bagi yang tunduk pada kentetuan dalam KUH Perdata. Hukum waris Islam berlaku bagi yang menganut agama Islam. Hukum waris adat berlaku bagi orang Indonesia asli (pribumi). Pluralism hukum waris tidak terbatas pada ketiga penggolongan tersebut. Pluralism hukum waris lebih kental terasa pada hukum waris adat yang diterapkan di daerah masingmasing di Indonesia. Hukum waris adat sangat dipengaruhi oleh system kekerabatan yang dianut masyarakat setempat. Tiga system kekerabatan yang berlaku di Indonesia yaitu parilineal, matrilineal dan prental.

Bali adalah salah satu daerah yang menganut system kekerabatan patrilineal. System kekerabatan ini mengakui garis keturunan berdasarkan garis laki-laki. System ini membawa pengaruh besar pada hukum waris adat Bali yang menempatkan laki-laki sebagai penerus utama dalam keluarga dan menempatkan perempuan sebagai pihak subordinat dahal hal waris. Perempuan (belum kawin) maupun yang telah menjanda (karena kematian dan perceraian) dianggap tidak berhak atas harta warisan kelaurga dan suami. Perempuan (janda karena kematian) hanya berhak memanfaatkan harta peninggalan suaminya, tidak memilikinya. Paradigma itu tetap tumbuh dan hidup dalam masyarakat Bali hingga kini. Perubahan social masyarakat serta tuntutan kaum feminist atas kesetaraan belum membawa banyak perubahan pada kedudukan perempuan (janda karena kematian) atas harta warisan suami. Kehadiran ketentuan-ketantuan seperti Keputusan Pesamuan Agung III MUDP Bali No. 01/Kep/PSM-3MDP Bali/X/2010, 15 Oktober 2010, Putusan Pengadilan Tinggi Bali tanggal 7 November 1967 No. 228/PDT/1966/PDT, Putusan Mahkamah Agung Nomor 4766 K/Pdt/1998 tertanggal 16 November 1999, Putusan Mahkamah Agung tanggal $23 \quad$ Oktober 1961, No.179/K/SIP/1961 tidak serta merta dapat menggeser paradigma masyarakat bahwa perempuan (janda karena kematian) berhak atas harta warisan suami terlebih ketika tidak ada anak yang lahir dari perkawainan tersebut. Kenyataan yang terjadi kedudukan perempuan (lajang maupun janda karena kematian) tetap 
lemah sebagai ahli waris dan diabaikan. Perlakuan tidak adil tetap terjadi karena hegemoni laki-laki dalam mempertahankan system patrilineal yang berlaku di Bali. system yang memandang bahwa laki-laki adalah penerus keluarga sekaligus yang bertanggung jawab dan berhak menguasai harta warisan keluarga.

\section{DAFTAR PUSTAKA}

Alkostar. A.. \& Amin. M. S. (1986). Pembanqunan Hukum Persoektif Politik Hukum Nasional. Rajawali, Jakarta.

Astiwi. (2007). Sosiologi, Sinar Mandiri, Klaten.

Bernard L. Tanya, Yoan N. Simanjuntak dan Markus Y. Hage. (2010). Teori Hukum Strategi Tertib Manusia Lintas Ruang dan Generasi. Genta Publishing, Yogyakarta.

Bushar. M. (1988). Asas-Asas Hukum Adat Suatu Pengantar. Pradnya Paramita, Jakarta.

Fadjar, A. M. (2013). Teori-Teori Hukum Kontemporer. Setara, Malang.

Harum, I. G. P. M., \& Kusuma, A. G. A. D. Kedudukan Ahli Waris Perempuan Bali Dalam Perspektif Hukum Waris Di Indonesia. Bagian Hukum Perdata FH-UNUD, Denpasar.

Otje Salman dan Anthon F. Susanto. (2009). Teori Hukum Mengingat, Mengumpulkan dan Membuka Kembali. Refika Aditama, Bandung.

PNH Simanjuntak, S. H. (2017). Hukum Perdata Indonesia. Kencana.

Panetje, G. (2004). Aneka Catatan Tentang Hukum Adat Di Bali. CV. Kayumas Agung.

Patricia Smith in Patterson, D. M. (Ed.). (2010). A companion to philosophy of law and legal theory. West Sussex: Blackwell.
Ratna Megawangi. (1999). Membiarkan Berbeda: Sudut Pandang Baru tentang Relasi Gender. Mizan, Bandung.

Soekanto, S., Suvanto, C., \& Widodo, H. (1993). Pendekatan Sosioloai Terhadap Hukum. Bina Aksara, Jakarta.

Soerojo Wignjodipoero, S. H. (1982). Kedudukan Serta Perkembangan Hukum Adat Setelah Kemerdekaan. Gunung Agung, Jakarta.

Soeroso, M. H. (2010). Kekerasan Dalam Rumah Tangga Dalam Perspektif Yuridis-Viktimologis. Sinar Grafika, Jakarta.

Sudiyat, I. (1981). HukumAadat: Sketsa Asas. Liberty Yogyakarta.

Sugangga, I. G. N. (1988). Hukum Adat Waris pada Masyarakat Hukum Adat yang Bersistem Patrilineal di Indonesia, Semarang.

Suparman, E., \& Gunarsa, A. (2005). Hukum waris Indonesia: dalam perspektif Islam, adat, dan $B W$. PT Refika Aditama.

Taneko. S. B. (1993). Pokok-Pokok Studi Hukum dalam Masvarakat. Raja Grafindo Persada,Jakarta.

Wayan P. Windia, Ni Made Wiasti dan Ni Luh Arjani. (2012). Pewarisan Perempuan Menurut Hukum Adat di Bali. Udayana University Press, Denpasar.

E- Journals:

Benni, B. (2015). Pewarisan pada Etnis Tionghoa dalam Pluralitas Hukum Waris di Indonesia. Masalah-Masalah Hukum, 44(1).

Olivia, F., \& Lubis, a. (2007). Kedudukan Janda Dalam Hukum Waris Adat Batak. Lex Jurnalica Vol.4 No.3, Agustus.

Sukerti, N. N. (2011). Perkembangan Hak Perempuan Di Bidang Waris Dalam Hukum Adat Bali. Masalah-Masalah Hukum, 40(1). 